\title{
Efficacy of domiciliary noninvasive ventilation on clinical outcomes in posthospital chronic obstructive pulmonary disease patients: a meta-analysis of randomized controlled trials
}

\author{
Xue $\mathrm{He}^{1,2,3}$, Lijuan Luo ${ }^{1,2,3}$, Yiming $\mathrm{Ma}^{1,2,3}$, Yan Chen $^{1,2,3}$ \\ ${ }^{1}$ Department of Pulmonary and Critical Care Medicine, The Second Xiangya Hospital, Central South University, Changsha, China; ${ }^{2}$ Research \\ Unit of Respiratory Disease, Central South University, Changsha, China; ${ }^{3}$ Diagnosis and Treatment Center of Respiratory Disease, Central South \\ University, Changsha, China \\ Contributions: (I) Conception and design: X He, Y Chen; (II) Administrative support: Y Chen; (III) Provision of study materials or patients: Y Ma, \\ Y Chen; (IV) Collection and assembly of data: X He, L Luo, Y Ma; (V) Data analysis and interpretation: X He, Y Ma; (VI) Manuscript writing: All \\ authors; (VII) Final approval of manuscript: All authors. \\ Correspondence to: Yan Chen, MD, PhD. Department of Pulmonary and Critical Care Medicine, The Second Xiangya Hospital, Central South \\ University, No. 139 Middle Renmin Road, Changsha 410011, China. Email: chenyan99727@csu.edu.cn.
}

\begin{abstract}
Background: As newly emerging evidence was given, we conducted a meta-analysis of randomized controlled trials (RCTs) with the following objectives: (I) to evaluate the effect of long-term noninvasive ventilation (NIV) on posthospital chronic obstructive pulmonary disease (COPD) patients with respiratory failure in mortality, blood gas, exacerbation frequency; (II) to distinguish different follow-up length of longterm NIV and its effect on these outcomes.

Methods: We tried to conduct and report this meta-analysis in accordance with the Cochrane Handbook (version 5.1.0) by searching the PubMed, Embase, Cochrane Library, and Chinese Biomedical Literature for RCTs in humans through April 2020. Studies comparing treatment effects of domiciliary NIV with control therapy in posthospital COPD patients were conducted, and at least one of the following parameters were reviewed: mortality, gas exchange, and exacerbation frequency.

Results: Five studies with 419 subjects were identified. The exacerbation frequency significantly decreased in patients who received domiciliary NIV [weighted mean difference (WMD) $-1.74,95 \% \mathrm{CI}:-2.90$ to -0.57 , $\mathrm{P}=0.004]$. No significant difference was found in mortality, partial pressure of arterial oxygen $\left(\mathrm{PaO}_{2}\right), \mathrm{PaCO}_{2}$, and $\mathrm{pH}$. Subgroup analysis of $\mathrm{PaCO}_{2}$ showed that domiciliary NIV of 3 months was most likely to decrease $\mathrm{PaCO}_{2}$, but not significant (WMD -2.95, 95\% CI: -6.11 to $0.21, \mathrm{P}=0.07$ ).

Discussion: The results indicate that domiciliary NIV decreases the exacerbation frequency of posthospital COPD patients, but may not improve mortality or gas exchange. Further studies are needed to evaluate the benefit of domiciliary NIV on COPD patients.
\end{abstract}

Keywords: Chronic obstructive pulmonary disease (COPD); meta-analysis; domiciliary NIV; mortality; gas change; exacerbation frequency

Submitted Oct 13, 2020. Accepted for publication Mar 24, 2021.

doi: 10.21037/apm-20-2017

View this article at: http://dx.doi.org/10.21037/apm-20-2017

\section{Introduction}

Chronic obstructive pulmonary disease (COPD) is a common chronic lung disease, which is predicted to be the $3^{\text {rd }}$ leading cause of death by 2020 (1). COPD has induced huge burden globally because of the increasing morbidity and mortality, especially in developing countries. The destruction of gas-exchanging surfaces of the alveolar, called emphysema, is the main pathological 
changes of COPD. As disease progresses, hypoxemia and hypercapnia are the common gas exchange abnormalities. Meanwhile, airflow limitation contributes to the high possibility of exacerbations and death (2-4). Oxygen therapy and ventilation support are essential steps on improve hypoxemia and hypercapnia. Goals of COPD management are reducing the risk of exacerbations and minimizing the negative impact of exacerbations.

The applying of noninvasive mechanical ventilation (NIV) is considered priority to treat acute respiratory failure in hospitalized AECOPD patients (5). Evidence showed that NIV could improve mortality during hospitalization and reduce the use of endotracheal intubation (6,7). Mild acidosis ( $\mathrm{pH} 7.30-7.35)$ patients were most likely to benefit from NIV during acute hypercapnic respiratory failure (5). There is insufficient evidence to support long-term NIV in non-acute COPD patients so far $(8,9)$, including blood gas, mortality, lung function and so on. As shown in the ECLIPSE cohort, prior hospital admission of AECOPD was associated with the highest risk of a new hospitalization (2). Therefore, the beginning time of using NIV might have effect on the outcomes. In recent years, several randomized controlled trials (RCTs) concerning posthospital AECOPD patients have been published.

As newly emerging evidence was given, we conducted a meta-analysis of RCTs with the following objectives: (I) to evaluate the effect of long-term NIV on posthospital COPD patients with respiratory failure in mortality, blood gas, exacerbation frequency; (II) to distinguish different subgroups of long-term NIV and its effect on these outcomes. We present the following article in accordance with the PRISMA reporting checklist (available at http:// dx.doi.org/10.21037/apm-20-2017).

\section{Methods}

\section{Literature search}

We attempted to conduct and report this meta-analysis in accordance with the Cochrane Handbook (version 5.1.0) by searching the PubMed, Embase, Cochrane Library, and Chinese Biomedical Literature for RCTs in humans through April 2020. We used search terms "Pulmonary Disease, Chronic Obstructive," or "COPD," in combination with "noninvasive ventilation" and "randomized controlled trial." No restrictions were imposed. In addition, we reviewed the reference lists of retrieved studies and recent reviews. We did not contact authors of original studies for additional information. No attempt was made to identify unpublished reports.

\section{Study selection and eligibility criteria}

Study selection was based on an initial screen of identified abstracts or titles and the second screen of full-text articles. Studies were considered eligible if they met the following criteria: (I) the study design was a RCT; (II) posthospital COPD patients were included (post-hospital COPD is defined as those who has clear evidence that treatment with NIV in a study after hospitalization (due to acute exacerbation or acute hypercapnia). Usually, refer to those who have acute exacerbation within 4 weeks); (III) domiciliary noninvasive ventilation (NIV) was used in the intervention group, and usual care was used in the control group; (IV) measurement of mortality, gas exchange, or exacerbation frequency. First, two reviewers independently screened titles and abstracts of the studies according to eligibility criteria. And if the studies met the eligibility criteria, full texts were reviewed for further selection. Two reviewers' results were compared, and disagreements were resolved by discussion.

\section{Data extraction}

We recorded study characteristics as follows: (I) name of the first author, publication year, and country of origin; (II) study design; (III) number of cases; (IV) length of follow-up; (V) main characteristics of the subjects; (VI) interventions; (VII) outcomes. Two reviewers (XH and LJL) independently performed the literature search, study selection, and data extraction. Any disagreements were resolved by discussion.

\section{Statistical analysis}

Our main analysis focused on the different outcomes of intervention on posthospital COPD patients. The risk of bias was assessed based on the Cochrane Handbook. Mean and variance was extracted from the article directly or concerted from median, range, and the size of a sample (10). The relative risk (RR) and weighted mean difference (WMD) were used as the common measure of association across different studies $(11,12)$. Review Manager (version 5.3.5) was used to analyze the results and assess the intervention efficacy (13). The risk of bias in individual 


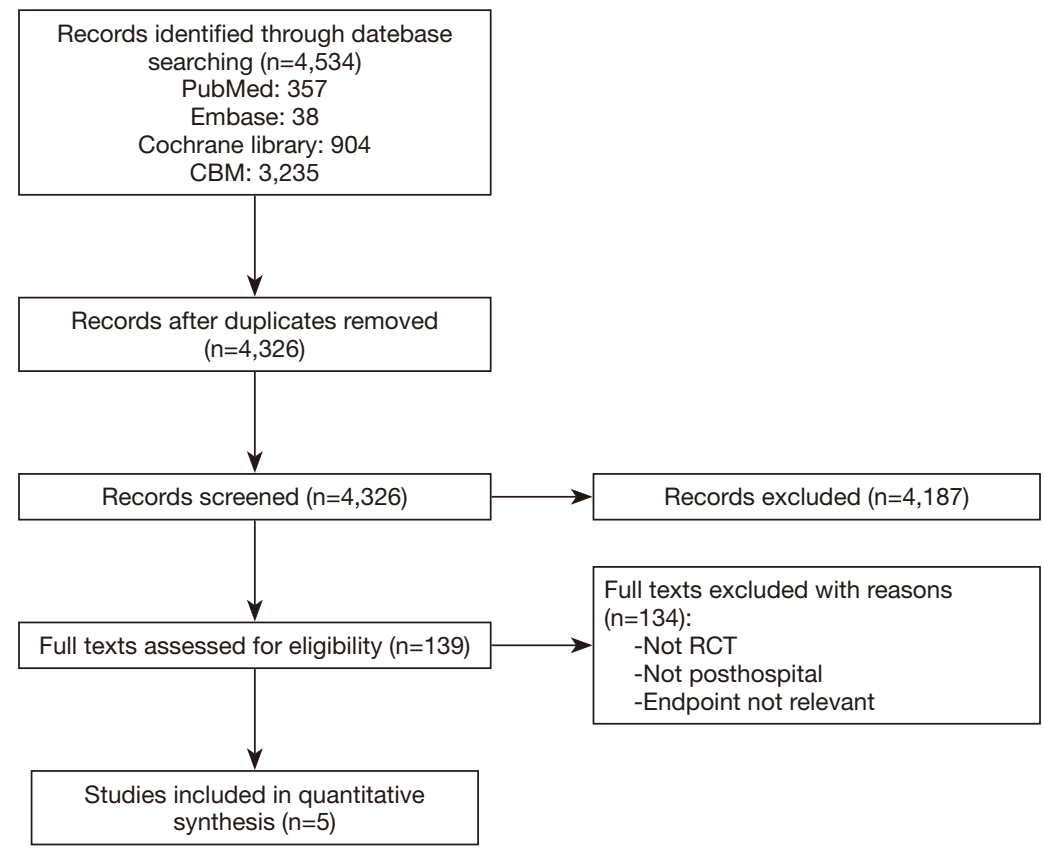

Figure 1 Flow chart of the study selection.

studies was assessed using this software following the PRISMA statement. A random efficacy model was used in the case of significant heterogeneity among studies. RR with $95 \%$ confidence interval $(95 \% \mathrm{CI})$ was computed for discontinuous variable; WMD with 95\% CI was calculated for continuous variable. Homogeneity of RRs was evaluated by $Q$ statistic (significance level at $\mathrm{P}<0.1$ ) and $\mathrm{I}^{2}$ statistic (12). For $\mathrm{I}^{2}$ statistic, $\mathrm{I}^{2}<25 \%, 25 \% \leq \mathrm{I}^{2}<50 \%$ or $\mathrm{I}^{2} \geq 50 \%$ corresponds to the low, moderate or high significance of heterogeneity, respectively. We conducted subgroup analysis stratified by follow-up length. We also conducted a sensitivity analysis to investigate the influence of a single study on the overall risk estimate by omitting one study in each turn.

\section{Results}

\section{Literature search and study characteristics}

A flow chart showing the study selection is presented in Figure 1. Five studies met the eligible criteria after our complete review. The characteristics of these studies are presented in Table 1. These RCTs studies were published between 2007 and 2017. Two studies were conducted in China (14,15), one in Belgium (16), one in Netherland (17), and one in England (18). Two studies were multicenter
RCTs $(17,18)$, and three studies were single-center RCTs (14-16). The number of patients enrolled in the original studies ranged from 40 to 201, with a sum of 419 . Of them, 211 were in NIV intervention, and 208 of them were in the control group. The follow-up ranged from 6-24 months. 3 studies reported 12 months, 1 reported 6 months, 1 reported 24 months. The risk of bias assessment (including selection bias, performance bias, detection bias, attrition bias, reporting bias, etc.) was shown in Figure 2. All the studies claimed RCTs, but De Backer's study didn't show the randomized method. De Backer's and Xiang's study were assessed unclear risk of allocation concealment. Only Cheung reported a blinded intervention to participants. Two studies clearly described the blinding of outcome assessment. Three studies were assessed a high risk of attrition bias. De Backer's study was a high risk of reporting bias, as only one time point result was reported.

\section{Mortality}

Three studies reporting mortality were summarized in Figure 3. Results from three studies on mortality were consistent, with most showing no relation with intervention. The summary RR comparing domiciliary NIV with control treatment was 0.87 (95\% CI: 0.59-1.28), with low heterogeneity $\left(\mathrm{P}=0.49, \mathrm{I}^{2}=20 \%\right)$. 
Table 1 Characteristics of the included studies

\begin{tabular}{|c|c|c|c|c|c|c|c|c|c|c|c|c|}
\hline Study & Location & Trial type & Patients recruited & $\begin{array}{l}\text { Population }(\mathrm{n}) \\
\text { randomized } \\
\text { (treatment/control) }\end{array}$ & $\begin{array}{l}\text { Length of } \\
\text { follow-up }\end{array}$ & $\begin{array}{l}\text { Main characteristics } \\
\text { of the subjects }\end{array}$ & Intervention (I/C) & Main outcomes & Baseline mean value (//C) & $\begin{array}{l}\text { NIV settings at } \\
\text { endpoint IPAP/ } \\
\text { EPAP }\left(\mathrm{cmH}_{2} \mathrm{O}\right)\end{array}$ & $\begin{array}{l}\text { Initial NIV } \\
\text { settings IPAP/ } \\
\text { EPAP }\left(\mathrm{cmH}_{2} \mathrm{O}\right)\end{array}$ & $\begin{array}{l}\text { Time of daily } \\
\text { use }\end{array}$ \\
\hline $\begin{array}{l}\text { Murphy } \\
\text { et al., } 2017\end{array}$ & England & $\begin{array}{l}\text { Multi-center } \\
\text { RCT }\end{array}$ & $\begin{array}{l}\text { Patients admitted with acute decompensated } \\
\text { hypercapnic exacerbations of COPD requiring } \\
\text { acute noninvasive ventilation were screened } \\
\text { for eligibility at least } 2 \text { weeks after resolution of } \\
\text { decompensated acidosis (arterial pH }>7.30 \text { ) and } \\
\text { within } 4 \text { weeks of attaining clinical stability }\end{array}$ & $116(57 / 59)$ & 12 months & $\begin{array}{l}\text { FEV1 }<50 \% \text { predicted, } \\
\mathrm{PaCO}_{2}>53 \mathrm{mmHg}\end{array}$ & $\begin{array}{l}\text { Home oxygen therapy } \\
+ \text { NIV/home oxygen } \\
\text { therapy alone }\end{array}$ & $\begin{array}{l}\text { Time to readmission or } \\
\text { death, mortality, exacerbation } \\
\text { frequency, PaCO } \\
\text { dyspnea, } \mathrm{HRQL}_{2} \text {, } \\
\text { Respiratory } \mathrm{George's} \\
\text { Restionnaire }\end{array}$ & $\begin{array}{l}\mathrm{PaO}_{2} 48 / 48 \mathrm{mmHg} \text {, } \\
\mathrm{PaCO}_{2} 59 / 59 \mathrm{mmHg}, \mathrm{pH} \\
7.4 / 7.4 \text {, admissions per } \\
\text { year not shown }\end{array}$ & $24 / 4$ & $18 / 4$ & $\begin{array}{l}\text { NIV: a minimum } \\
\text { of } 6 \text { hours } \\
\text { nightly; OT: at } \\
\text { least } 15 \text { hours } \\
\text { daily }\end{array}$ \\
\hline $\begin{array}{l}\text { Struik et al., } \\
2014\end{array}$ & Netherlands & $\begin{array}{l}\text { Multi-center } \\
\text { RCT }\end{array}$ & $\begin{array}{l}\text { COPD patients who were admitted to hospital with } \\
\text { ARF and treated with ventilatory support }\end{array}$ & $201(101 / 100)$ & 12 months & $\begin{array}{l}\text { FEV1 }<50 \% \text { predicted } \\
\mathrm{PaCO}_{2}>6 \mathrm{kPa}\end{array}$ & NIV + LTOT/LTOT & $\begin{array}{l}\text { Time to readmission or death, } \\
\text { lung function, arterial blood } \\
\text { gas, survival, admission and } \\
\text { exacerbation rates, HRQL }\end{array}$ & $\begin{array}{l}\mathrm{PaO}_{2} 59.25 / 56.25 \\
\mathrm{mmHg} \mathrm{PaCO} 2 \\
59.25 / 57.75 \mathrm{mmHg}, \mathrm{pH} \\
7.38 / 7.39 \text {, admissions } \\
\text { per year 2/2 }\end{array}$ & $21 / 5.2$ & $14 / 4$ & $\begin{array}{l}\text { NIV: at least } \\
5 \text { hours per } \\
\text { night; LTOT: at } \\
\text { least } 15 \text { hours } \\
\text { daily }\end{array}$ \\
\hline $\begin{array}{l}\text { De Backer } \\
\text { et al., } 2011\end{array}$ & Belgium & $\begin{array}{l}\text { Single center } \\
\text { RCT }\end{array}$ & $\begin{array}{l}\text { Hospitalized patients after acute hypercapnic } \\
\text { COPD exacerbations, were hospitalized due to an } \\
\text { exacerbation }\end{array}$ & $15(10 / 5)$ & 6 months & $\begin{array}{l}\text { FEV1 }<50 \% \text { predicted, } \\
\mathrm{PaCO}_{2}>45 \mathrm{mmHg}\end{array}$ & $\begin{array}{l}\text { NIV/no NIV, no details } \\
\text { about LTOT }\end{array}$ & $\begin{array}{l}\text { Arterial blood gas, functional } \\
\text { imaging of the lungs, lung } \\
\text { function tests (static and } \\
\text { dynamic lung volumes, } \\
\text { diffusion), exercise tolerance }\end{array}$ & $\begin{array}{l}\mathrm{PaO}_{2} 59 / 65 \mathrm{mmHg}, \\
\mathrm{PaCO}_{2} 55.4 / \\
52.4 \mathrm{mmHg}, \mathrm{pH} \text { not } \\
\text { shown, admissions per } \\
\text { year not shown }\end{array}$ & Not shown & Not shown & $\begin{array}{l}\text { NIV: at least } \\
5 \text { hours a day }\end{array}$ \\
\hline $\begin{array}{l}\text { Cheung } \\
\text { et al., } 2010\end{array}$ & China & $\begin{array}{l}\text { Single center } \\
\text { RCT }\end{array}$ & $\begin{array}{l}\text { COPD patients who were admitted to acidosis } \\
\text { hospital with ARF and treated with ventilatory } \\
\text { support }\end{array}$ & $47(23 / 24)$ & 12 months & $\mathrm{PaCO}_{2}>6 \mathrm{kPa}$ & $\begin{array}{l}\text { NIV/CPAP, LTOT if } \\
\text { appropriate }\end{array}$ & $\begin{array}{l}\text { Time to recurrent AHRF, } \\
\text { readmission, compliance, } \\
\text { severe adverse event, arterial } \\
\text { blood gas, all-cause mortality }\end{array}$ & $\begin{array}{l}\mathrm{PaO}_{2} \text { not shown, } \mathrm{PaCO}_{2} \\
57.75 / 54.75 \mathrm{mmHg}, \mathrm{pH} \\
\text { 7.4/7.4, admissions per } \\
\text { year not shown }\end{array}$ & $10-20 / 5$ & Not shown & $\begin{array}{l}\text { NIV/CPAP for } \\
8 \mathrm{~h} \text { during } \\
\text { sleep every } \\
\text { night }\end{array}$ \\
\hline $\begin{array}{l}\text { Xiang et al., } \\
2007\end{array}$ & China & $\begin{array}{l}\text { Single center } \\
\text { RCT }\end{array}$ & $\begin{array}{l}\text { Severe COPD patients who were admitted due to } \\
\text { AECOPD with type II respiratory failure }\end{array}$ & $40(20 / 20)$ & 24 months & $\begin{array}{l}\text { FEV1 }<50 \% \text { predicted, } \\
\mathrm{PaCO}_{2} \geq 55 \mathrm{mmHg}\end{array}$ & NIV + LTOT/LTOT & $\begin{array}{l}\text { Mortality, arterial blood gas, } \\
\text { severe adverse event, severe } \\
\text { exacerbations (readmission), } \\
\text { compliance }\end{array}$ & $\begin{array}{l}\mathrm{PaO}_{2} 55 / 54 \mathrm{mmHg} \text {, } \\
\mathrm{PaCO}_{2} \\
59.2 / 58.8 \mathrm{mmHg} \text {, } \mathrm{pH} \text { not } \\
\text { shown, admissions per } \\
\text { year } 3.7 / 3.6\end{array}$ & $16-20 / 2-4$ & Not shown & $\begin{array}{l}\text { NIV: at least } \\
8 \text { hours per } \\
\text { day; LTOT: at } \\
\text { least } 15 \text { hours } \\
\text { daily }\end{array}$ \\
\hline
\end{tabular}

RCT, randomized controlled trial; NIV, noninvasive ventilation; COPD, chronic obstructive pulmonary disease; IPAP, inspiratory positive airway pressure; EPAP, expiratory positive airway pressure: CPAP, continuous positive airway pressure; LTOT, long-term oxygen therapy. 


\section{Gas exchange}

All studies reported gas exchange data. Results from four studies on $\mathrm{PaO}_{2}$ were inconsistent, with most showing no difference with domiciliary NIV. The summary WMD of $\mathrm{PaO}_{2}$ comparing domiciliary NIV with control treatment was 2.48 (95\% CI: -3.24 to 8.20 ), with high heterogeneity $\left(\mathrm{P}=0.40, \mathrm{I}^{2}=81 \%\right.$, Figure 4). Results from five studies on $\mathrm{PaCO}_{2}$ were also inconsistent at the endpoint. The summary WMD of $\mathrm{PaCO} 2$ comparing domiciliary NIV

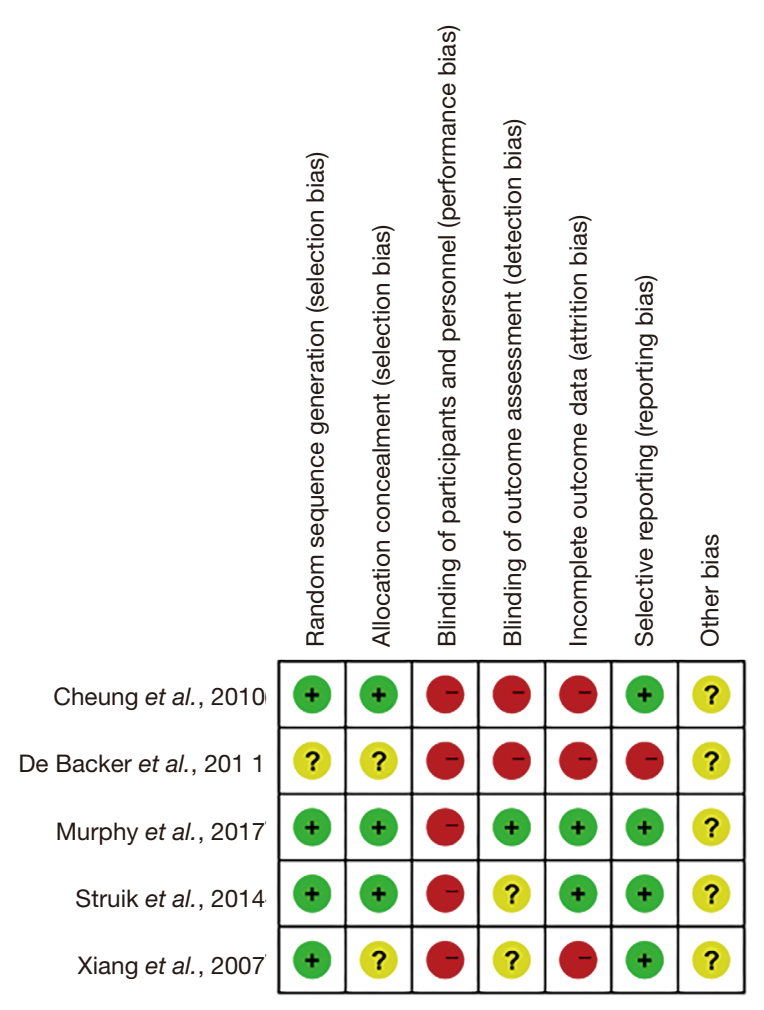

Figure 2 Risk of bias summary. +, low summary risk; ?, unclear risk; -, high risk. with control treatment was -4.42 (95\% CI: -10.63 to 1.78 ), with high heterogeneity $\left(\mathrm{P}=0.16, \mathrm{I}^{2}=93 \%\right.$, Figure 5). Only two studies included $\mathrm{pH}$ values. Results from two studies on $\mathrm{pH}$ were consistent. The summary WMD of $\mathrm{pH}$ comparing domiciliary NIV with control treatment was 0.01 (95\% CI: -0.00 to 0.02$)$, with no evidence of heterogeneity $(\mathrm{P}=0.13$, $\mathrm{I}^{2}=0 \%$, Figure 6).

\section{Exacerbation frequency}

Three studies reporting mortality were summarized in Figure 7. Results from three studies on exacerbation frequency were consistent. The summary WMD comparing domiciliary NIV with control treatment was -1.74 (95\% CI: -2.90 to -0.57$)$, with high heterogeneity $\left(\mathrm{P}=0.004, \mathrm{I}^{2}=75 \%\right.$, Figure 7).

\section{Subgroup and sensitivity analysis}

The results of $\mathrm{PaCO}_{2}$ subgroup analysis were presented in Figure 8, which were stratified by duration of followup. Two studies showed the data of 3 months, three studies each of 6 months and 12 months. Of all the subgroups, the summary WMD of $\mathrm{PaCO}_{2}$ comparing domiciliary NIV with control treatment was similar in total. For 3 months, the summary WMD was -2.95 (95\% CI: -6.11 to $0.21)$, with no evidence of heterogeneity $\left(\mathrm{P}=0.07, \mathrm{I}^{2}=0 \%\right)$. Results from two studies on $\mathrm{PaCO}_{2}$ were consistent, with both showing decrease with domiciliary NIV in 3 months. Similar data was shown in 12 months subgroup, which was -1.72 (95\% CI: -4.14 to 0.70$)$, with no evidence of heterogeneity $\left(\mathrm{P}=0.16, \mathrm{I}^{2}=0 \%\right)$. The result in 6 months seemed inverse relation, which was 0.38 (95\% CI: -2.92 to 3.69), with no evidence of heterogeneity $\left(\mathrm{P}=0.82, \mathrm{I}^{2}=0 \%\right)$.

The sensitivity analysis was to investigate whether a single study have influence on the overall risk estimate by

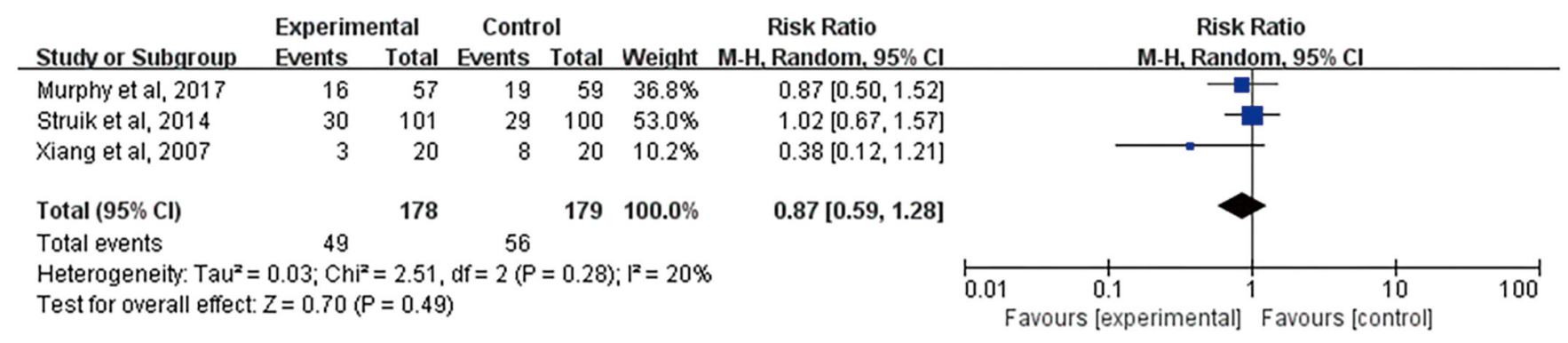

Figure 3 Mortality forest plot. Experimental, domiciliary NIV; control, usual care. 


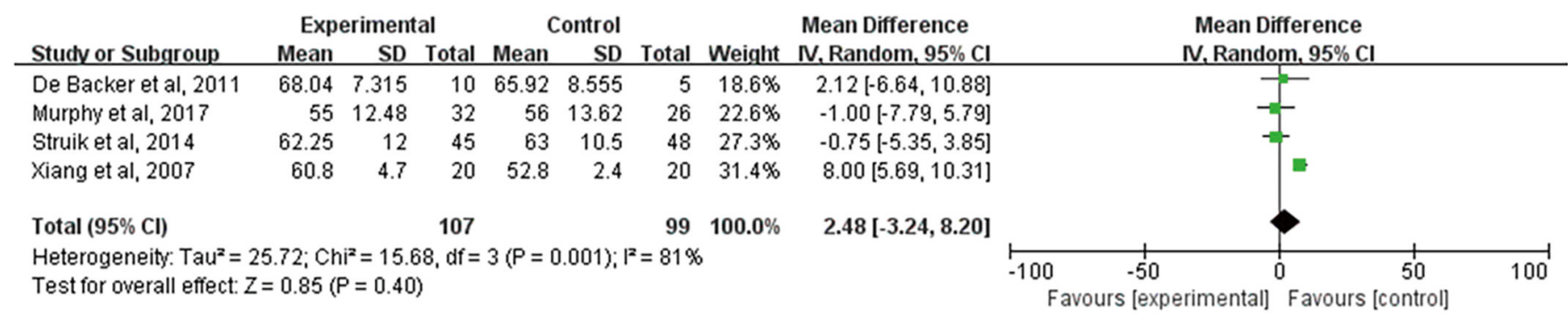

Figure $4 \mathrm{PaO}_{2}$ forest plot. Experimental, domiciliary NIV; control, usual care.

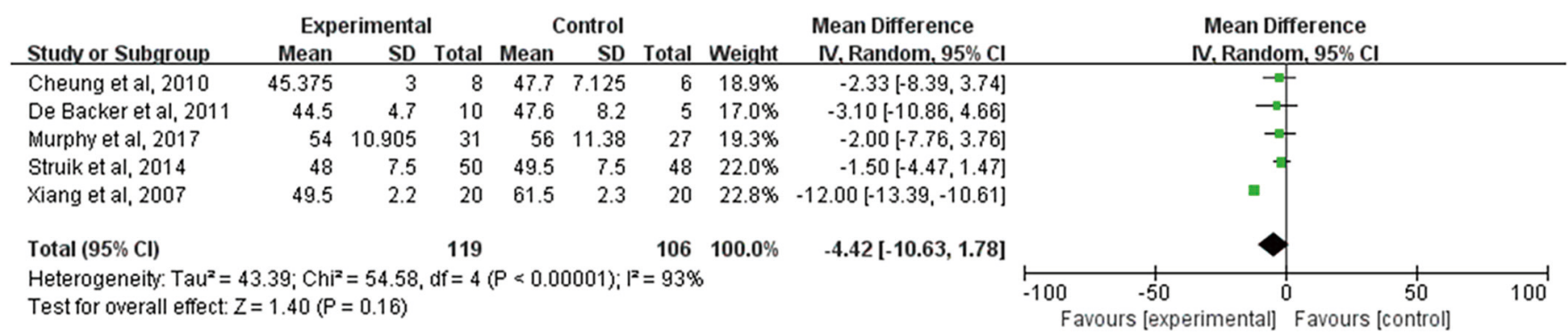

Figure $5 \mathrm{PaCO}_{2}$ forest plot. Experimental, domiciliary NIV; control, usual care.

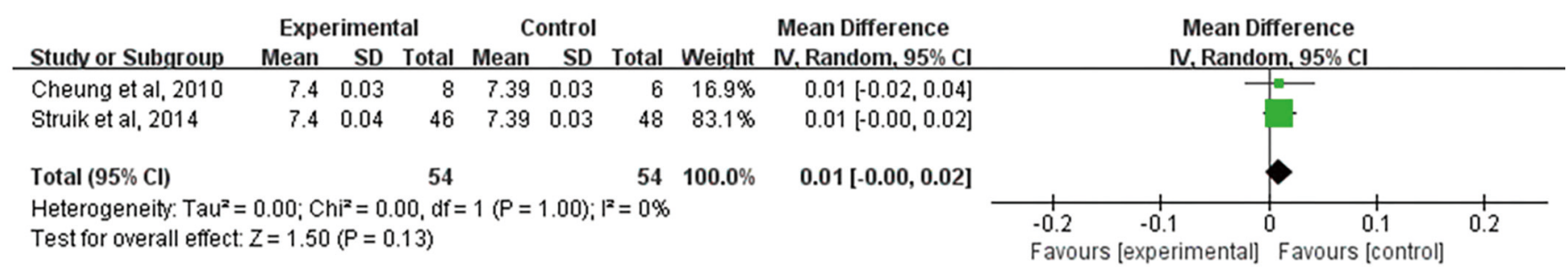

Figure $6 \mathrm{pH}$ forest plot. Experimental, domiciliary NIV; control, usual care.

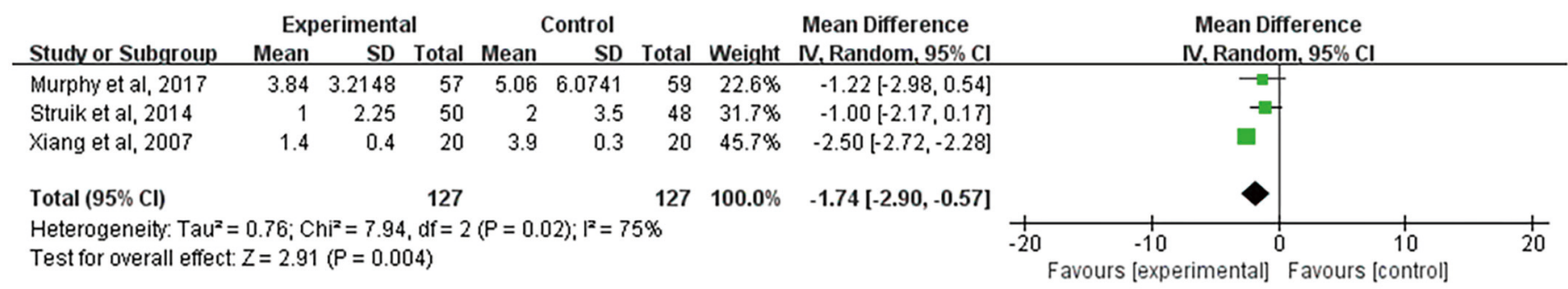

Figure 7 Exacerbation frequency forest plot. Experimental, domiciliary NIV; control, usual care.

omitting one single study in turn. For mortality, $\mathrm{PaO}_{2}$, $\mathrm{PaCO}_{2}$, and exacerbation frequency, the heterogeneity was attributed to one study (15). When omitting this study, the $\mathrm{I}^{2}$ turned to $0 \%$ in the above analysis, and the overall
$\mathrm{P}$ value remained similar. Two reviewers went through this study again and found that there was no reason to exclude the study. For mortality, after omitting this study, the result changed from $(\mathrm{WMD}=0.87,95 \% \mathrm{CI}: 0.59-1.28, \mathrm{P}=0.49$, 


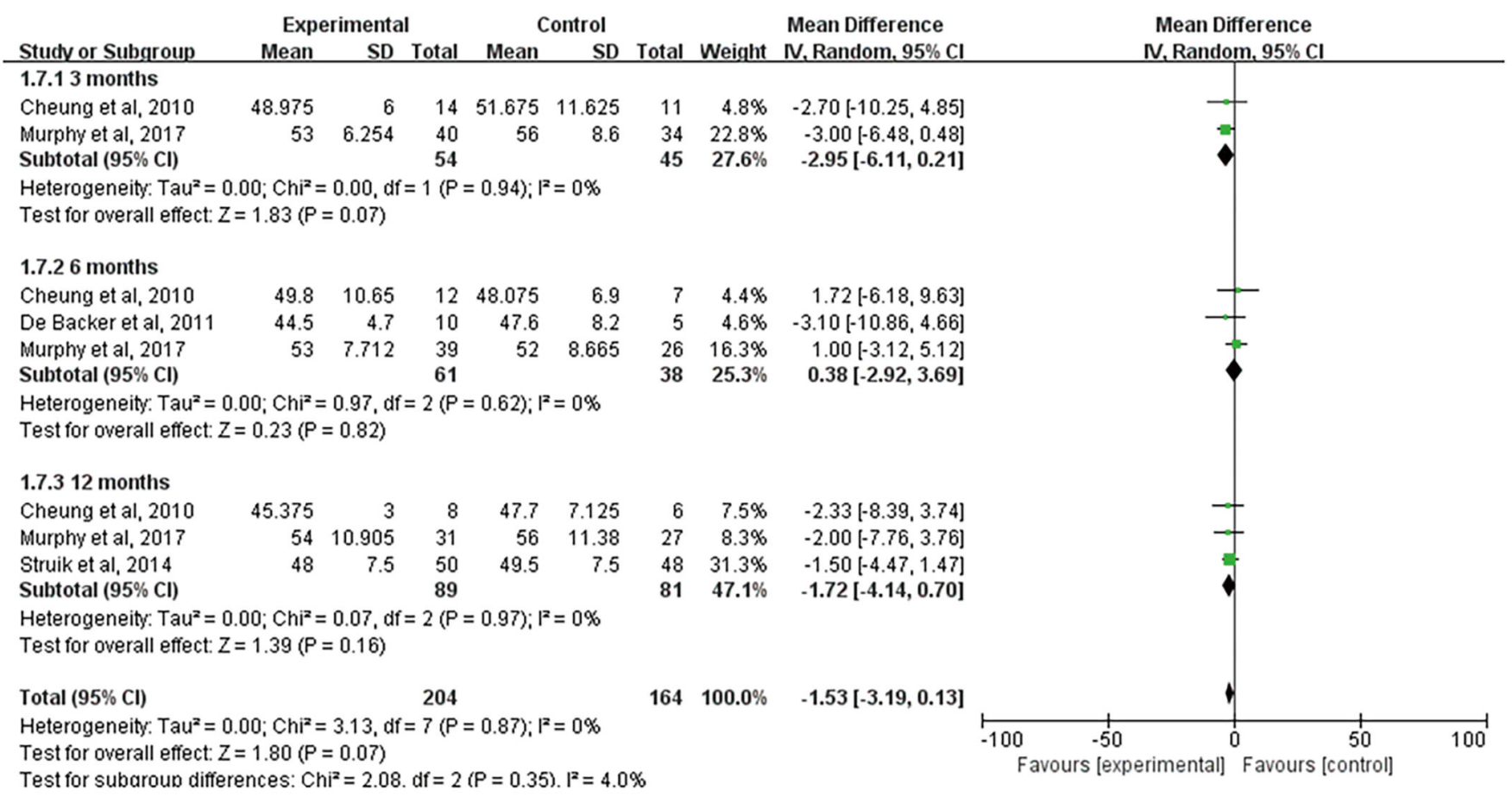

Figure 8 Subgroup analysis of $\mathrm{PaCO}_{2}$ based on follow-up durations. Experimental, domiciliary NIV; control, usual care.

$\left.\mathrm{I}^{2}=20 \%\right)$ to $(\mathrm{WMD}=0.96,95 \% \mathrm{CI}: 0.69-1.35, \mathrm{P}=0.83$, $\left.\mathrm{I}^{2}=0 \%\right)$. For $\mathrm{PaO}_{2}$, after omitting this study, the result changed from (WMD $=2.48,95 \% \mathrm{CI}:-3.24$ to $8.20, \mathrm{P}=0.4$, $\left.\mathrm{I}^{2}=81 \%\right)$ to (WMD $=-0.36,95 \% \mathrm{CI}:-3.85$ to $3.13, \mathrm{P}=0.84$, $\mathrm{I}^{2}=0 \%$ ). For $\mathrm{PaCO}_{2}$, after omitting this study, the result changed from (WMD $=-4.42,95 \% \mathrm{CI}:-10.63$ to 1.78 , $\left.\mathrm{P}=0.16, \mathrm{I}^{2}=93 \%\right)$ to (WMD $=-1.84,95 \% \mathrm{CI}:-4.15$ to 0.47 , $\mathrm{P}=0.12, \mathrm{I}^{2}=0 \%$ ). For exacerbation frequency, after omitting this study, the result changed from (WMD $=-1.74,95 \% \mathrm{CI}$ : -2.90 to $\left.-0.57, \mathrm{P}=0.004, \mathrm{I}^{2}=75 \%\right)$ to (WMD $=-1.07,95 \%$ CI: -2.04 to $\left.-0.09, \mathrm{P}=0.03, \mathrm{I}^{2}=0 \%\right)$.

\section{Discussion}

It is recognized that recurrent exacerbations leading to short-term readmission and increased all-cause mortality are associated with the initial hospitalization for an acute episode of deterioration (1). So, the treatment and management of posthospital COPD patients with acute exacerbation were essential. The applying of NIV is strongly recommended to treat acute respiratory failure in hospitalized AECOPD patients (1,5). Besides, the present meta-analysis of RCT studies supports a significant inverse association between NIV and $\mathrm{PaCO}_{2}$, as well as mortality in stable hypercapnic COPD patients (9). It usually takes 2 months to reach a stable stage. It was reported that the 28-day COPD readmission rate was around 20\% (19). Whether patients could benefit from the early starting of long-term NIV has been an urgent clinical question.

In our current meta-analysis, five RCTs were included with 419 posthospital COPD patients. The mortality, gas exchange, and exacerbation frequency were analyzed between the domiciliary NIV and control treatments. The exacerbation frequency significantly decreased in patients who received domiciliary NIV (WMD $-1.74,95 \%$ CI: -2.90 to $-0.57, \mathrm{P}=0.004)$. The result was consistent with Murphy's data (18), which is the latest posthospital RCT so far. Meanwhile, no significant difference was found in mortality, $\mathrm{PaO}_{2}, \mathrm{PaCO}_{2}$, and $\mathrm{pH}$. Unlikely with the meta-analysis of stable COPD, domiciliary NIV couldn't decrease $\mathrm{PaCO}_{2}$ for long-term effects in posthospital COPD patients. The subgroup analysis of $\mathrm{PaCO}_{2}$ showed that domiciliary NIV of 3 months was most likely decrease $\mathrm{PaCO}_{2}$, but still not significant (WMD $-2.95,95 \% \mathrm{CI}:-6.11$ to $0.21, \mathrm{P}=0.07$ ). In Murphy's study, there was significant improvement in hypercapnia during the follow-up duration of 6 weeks and 3 months. The long-term effect on the improvement of gas exchange may need to be evaluated. 
Sensitivity analysis showed that Xiang's study (15) was the origin of heterogeneity in mortality, $\mathrm{PaO}_{2}, \mathrm{PaCO}_{2}$, and exacerbation frequency. In this analysis, the left studies present great homogeneity by omitting Xiang's study. We reviewed Xiang's study again, found there was no reason to delete this study. The reason that attributes to the heterogeneity may be the small number and significant results.

In the disease progression, COPD was punctuated by acute exacerbations. The management of exacerbation in COPD patients is the most critical part of disease management. Based on GOLD 2020, one of the goals is to minimize the negative impact of current exacerbation and to prevent subsequent events. For the first part, we have enough evidence to support our current treatment for AECOPD or COPD with acute hypercapnia, including the early use of NIV in hospital, corticosteroids, bronchodilators. Since the readmission is still higher than imagine (19), the management of posthospital is in the spotlight. Gavish et al. (20) reported that early followup (within one month) following discharge should be undertaken when possible and has been related to less exacerbation-related readmissions. Additional followup at three months is recommended to ensure return to a stable clinical state and permit a review of the patient's symptoms, lung function, and where possible the assessment of prognosis using multiple scoring systems such as BODE (21). There is no doubted that patients could benefit from frequent follow-up. But in developing countries like China, the density of physicians (total number per 1,000 population) is far lower compared with developed countries (22). Early follow-up may not be able to accomplish in every hospital, especially those not teaching hospital. In this case, our findings may provide evidence for the use of long-term NIV in COPD patients after acute hypercapnia.

There are several limitations in this study. First, this study includes a high degree of heterogeneity. However, our sensitivity analysis indicated that after omitting one study $\mathrm{I}^{2}$ became $0 \%$. Deleting that study will not change the result. Second, we didn't attempt to identify unpublished papers. This may contribute to a publication bai. Third, the small numbers of RCTs were another limitation of this metaanalysis. Further studies are needed to confirm our findings. Fourth, better double-blind and sham masks should be taken into consideration in the clinical trials of NIV in the future. The traditional sham device with no pressure could result in the increasing of $\mathrm{PaCO}_{2}$. Unlikely pills, both patients and physicians can figure out positive pressure and zero pressure. The lack of double-blind practice is potential limitation in all NIV trials, and leads to performance and detection bias.

In summary, the results indicate that domiciliary NIV decreases the exacerbation frequency of posthospital COPD patients, but may not improve mortality and gas exchange. However, the analyses were based on small numbers of studies regarding posthospital AECOPD patients. Further studies are needed to evaluate the benefit of domiciliary NIV on COPD patients.

\section{Acknowledgments}

We would like to thank Anna Park for her help in polishing the language of our paper and all the participants involved in this study.

Funding: This study was supported by the National Science Foundation of China (81400032, 81600031, 81873410), and the National Key Clinical Specialty Construction Projects of China.

\section{Footnote}

Reporting Checklist: The authors have completed the PRISMA reporting checklist. Available at http://dx.doi. org/10.21037/apm-20-2017

Conflicts of Interest: All authors have completed the ICMJE uniform disclosure form (available at http://dx.doi. org/10.21037/apm-20-2017). The authors have no conflicts of interest to declare.

Ethical Statement: The authors are accountable for all aspects of the work in ensuring that questions related to the accuracy or integrity of any part of the work are appropriately investigated and resolved.

Open Access Statement: This is an Open Access article distributed in accordance with the Creative Commons Attribution-NonCommercial-NoDerivs 4.0 International License (CC BY-NC-ND 4.0), which permits the noncommercial replication and distribution of the article with the strict proviso that no changes or edits are made and the original work is properly cited (including links to both the formal publication through the relevant DOI and the license). See: https://creativecommons.org/licenses/by-nc$\mathrm{nd} / 4.0 \%$. 


\section{References}

1. Committee TGS. Global Strategy for Prevention, Diagnosis and Management of COPD 2020 Report. Available online: https://goldcopd.org/gold-reports/

2. Müllerova H, Maselli DJ, Locantore N, et al. Hospitalized exacerbations of COPD: risk factors and outcomes in the ECLIPSE cohort. Chest 2015;147:999-1007.

3. Agusti A, Calverley PM, Celli B, et al. Characterisation of COPD heterogeneity in the ECLIPSE cohort. Respir Res 2010;11:122.

4. Soriano JB, Lamprecht B, Ramirez AS, et al. Mortality prediction in chronic obstructive pulmonary disease comparing the GOLD 2007 and 2011 staging systems: a pooled analysis of individual patient data. Lancet Respir Med 2015;3:443-50.

5. Osadnik CR, Tee VS, Carson-Chahhoud KV, et al. Non-invasive ventilation for the management of acute hypercapnic respiratory failure due to exacerbation of chronic obstructive pulmonary disease. Cochrane Database Syst Rev 2017;7:CD004104.

6. Corrêa TD, Sanches PR, de Morais LC, et al. Performance of noninvasive ventilation in acute respiratory failure in critically ill patients: a prospective, observational, cohort study. BMC Pulm Med 2015;15:144.

7. Mukherjee R, Nenna R, Turner A. Early ward-based acute noninvasive ventilation: a paper that changed practice. Breathe (Sheff) 2018;14:153-5.

8. Struik FM, Lacasse Y, Goldstein RS, et al. Nocturnal noninvasive positive pressure ventilation in stable COPD: a systematic review and individual patient data metaanalysis. Respir Med 2014;108:329-37.

9. Liao H, Pei W, Li H, et al. Efficacy of long-term noninvasive positive pressure ventilation in stable hypercapnic COPD patients with respiratory failure: a meta-analysis of randomized controlled trials. Int J Chron Obstruct Pulmon Dis 2017;12:2977-85.

10. Hozo SP, Djulbegovic B, Hozo I. Estimating the mean and variance from the median, range, and the size of a sample. BMC Med Res Methodol 2005;5:13.

11. DerSimonian R, Laird N. Meta-analysis in clinical trials revisited. Contemp Clin Trials 2015;45:139-45.

12. Higgins JP, Thompson SG, Deeks JJ, et al. Measuring inconsistency in meta-analyses. BMJ 2003;327:557-60.

13. DerSimonian R, Laird N. Meta-analysis in clinical trials. Control Clin Trials 1986;7:177-88.
14. Cheung AP, Chan VL, Liong JT, et al. A pilot trial of noninvasive home ventilation after acidotic respiratory failure in chronic obstructive pulmonary disease. Int J Tuberc Lung Dis 2010;14:642-9.

15. Xiang PC, Zhang X, Yang JN, et al. The efficacy and safety of long term home noninvasive positive pressure ventilation in patients with stable severe chronic obstructive pulmonary disease. Zhonghua Jie $\mathrm{He} \mathrm{He} \mathrm{Hu}$ Xi Za Zhi 2007;30:746-50.

16. De Backer L, Vos W, Dieriks B, et al. The effects of long-term noninvasive ventilation in hypercapnic COPD patients: a randomized controlled pilot study. Int J Chron Obstruct Pulmon Dis 2011;6:615-24.

17. Struik FM, Sprooten RT, Kerstjens HA, et al. Nocturnal non-invasive ventilation in COPD patients with prolonged hypercapnia after ventilatory support for acute respiratory failure: a randomised, controlled, parallel-group study. Thorax 2014;69:826-34.

18. Murphy PB, Rehal S, Arbane G, et al. Effect of Home Noninvasive Ventilation With Oxygen Therapy vs Oxygen Therapy Alone on Hospital Readmission or Death After an Acute COPD Exacerbation: A Randomized Clinical Trial. JAMA 2017;317:2177-86.

19. Suh ES, Mandal S, Harding R, et al. Neural respiratory drive predicts clinical deterioration and safe discharge in exacerbations of COPD. Thorax 2015;70:1123-30.

20. Gavish R, Levy A, Dekel OK, et al. The Association Between Hospital Readmission and Pulmonologist Follow-up Visits in Patients With COPD. Chest 2015;148:375-81.

21. Oga T, Tsukino M, Hajiro T, et al. Predictive properties of different multidimensional staging systems in patients with chronic obstructive pulmonary disease. Int J Chron Obstruct Pulmon Dis 2011;6:521-6.

22. Organization WH. Density of physicians (total number per 1000 population, latest available year). Available online: https://www.who.int/gho/health_workforce/physicians_ density/en/

Cite this article as: $\mathrm{He} \mathrm{X}$, Luo L, Ma Y, Chen Y. Efficacy of domiciliary noninvasive ventilation on clinical outcomes in posthospital chronic obstructive pulmonary disease patients: a meta-analysis of randomized controlled trials. Ann Palliat Med 2021;10(5):5137-5145. doi: 10.21037/apm-20-2017 